4. Price EH, Brain A, Dickson JA. An outbreak of infection with a gentamicin and methicillin-resistant Staphylococcus aureus in a neonatal unit. $J$ Hosp Infect 1980;1(3):221-228.

5. Anagnostakis D, Fitsialos J, Koutsia C, Messaritakis J, Matsaniotis N. A nursery outbreak of Serratia marcescens infection. Am J Dis Child 1981;135:413-414.

6. Dunkle LM, Naqvi SH, McCallum R, Lofgren JP. Eradication of epidemic methicillin-gentamicin-resistant Staphylococcus aureus in an intensivecare nursery. Am J Med 1981;70:455-458.

7. Christensen GD, Korones SB, Reed L, Bulley R, McLaughlin B, Bisno AL. Epidemic Serratia marcescens in a neonatal intensive care unit: importance of the gastrointestinal tract as a reservoir. Infect Control 1982;3:127-133.

8. Reboli A, John Jr J, Levkoff AH. Epidemic methicillin-gentamicin-resistant Staphylococcus aureus in a neonatal intensive care unit. Am J Dis Child 1989;143:34-39.

9. Zaidi M, Sifuentes J, Bobadilla M, Moncada D, Ponce de Leon S. Epidemic of Serratia marcescens bacteremia and meningitis in a neonatal unit in Mexico City. Infect Control Hosp Epidemiol 1989;10:14-20.

10. Campbell JR, Diacovo T, Baker CJ. Serratia marcescens meningitis in neonates. Pediatr Infect Dis J 1992;11:881-886.

11. Haley RW, Cushion NB, Tenover FC, Bannerman TL, Dryer D, Ross J, et al. Eradication of endemic methicillin-resistant Staphylococcus aureus infections from a neonatal intensive care unit. J Infect Dis 1995;171:614624.

12. Back NA, Linnemann Jr CC, Staneck JL, Kotagal UR. Control of methicillin-resistant Staphylococcus aureus in a neonatal intensive care unit: use of intensive microbiologic surveillance and mupirocin. Infect Control Hosp Epidemiol 1996;17:227-231

13. Versalovic J, Schneider M, de Bruijn FJ, Lupski JR. Genomic fingerprinting of bacteria using repetitive sequence-based polymerase chain reaction. Methods in Molecular and Cellular Biology 1994;5:25-40.

14. Tenover FC, Arbeit RD, Goering RV, Mickelsen PA, Murray BE, Persing $\mathrm{DH}$, et al. Interpreting chromosomal DNA restriction patterns produced by pulsed-field gel electrophoresis: criteria for bacterial strain typing. $J$ Clin Microbiol 1995;33:2233-2239.
15. Tenover FC, Arbeit R, Archer G, Biddle J, Byrne S, Goering R, et al. Comparison of traditional and molecular methods of typing isolates of Staphylococcus aureus. J Clin Microbiol 1994;32:407-415.

16. Hemming VG, Overall JC, Britt MR. Nosocomial infections in a newborn intensive-care unit. N Engl J Med 1976;294:1310-1316.

17. Baker CJ. Nosocomial septicemia and meningitis in neonates. Am J Med 1981;70:698-701.

18. Barrett FF, McGehee RF Jr, Finland M. Methicillin-resistant Staphylococcus aureus at Boston City Hospital: bacteriologic and epidemiologic observations. N Engl J Med 1968;279:441-448.

19. Graham DR, Correa-Villasenor A, Anderson RL, Vollman JH, Baine WB. Epidemic neonatal gentamicin-methicillin-resistant Staphylococcus aureus infection associated with nonspecific topical use of gentamicin. $J$ Pediatr 1980;97:972-978.

20. Goldman DA, Durbin Jr WA, Freeman J. Nosocomial infections in a neonatal intensive care unit. J Infect Dis 1981;144:449-459.

21. Haley RW, Bregman DA. The role of understaffing and overcrowding in recurrent outbreaks of staphylococcal infection in a neonatal specialcare unit. J Infect Dis 1982;145:875-885.

22. Gezon HM, Schaberg MJ, Klein JO. Concurrent epidemics of Staphylococcus aureus and group A streptococcus disease in a newborn nursery-control with penicillin $\mathrm{G}$ and hexachlorophene bathing. Pediatrics 1973;51:383-390.

23. Wilson CS, Stevenson DK, Arvin AM. A concurrent epidemic of respiratory syncytial virus and echovirus 7 infections in an intensive care nursery. Pediatr Infect Dis J 1989;8:24-29.

24. Boyce JM. Preventing staphylococcal infections by eradicating nasal carriage of Staphylococcus aureus: proceeding with caution. Infect Control Hosp Epidemiol 1996;17:775-779.

25. Lessing MPA, Jordens JZ, Bowler ICJ. When should healthcare workers be screened for methicillin-resistant Staphylococcus aureus? J Hosp Infect 1996;34:205-210.

\title{
Glycopeptide-Resistant Enterococcus faecium
}

Gina Pugliese, RN, MS Martin S. Favero, $\mathrm{PhD}$

Thal and coworkers from Wayne State University in Detroit conducted a study to evaluate the molecular relatedness of clinical isolates of glycopeptide-resistant Enterococcus faecium isolates collected from hospitals in Michigan. The 379 isolates used in this study all were vancomycinresistant $E$ faecium isolates collected from 28 hospitals and three extendedcare facilities from 1991 to 1996 . There were 73 pulsed-field gel electrophoresis (PFGE) strain types; within strain types, there were as many as six restriction fragment differences. Most isolates $(70 \%)$ belonged to 1 of 6 strain types, which were designated M1 (36\%), M2 (3\%), M3 (18\%), M4 (6\%), M10 (4\%), and M11 (3\%).

PFGE strain M1 was isolated from 135 patients in 13 hospitals dur- ing the period 1993 to 1996 . Strain type M2 was isolated from 11 patients in two hospitals during the period 1991 to 1992 and was not observed after 1992. Strain type M3 was isolated from 70 patients in 10 hospitals during the period of 1994 to 1996. M4 and M10 were isolated from 23 patients in 3 hospitals and from 15 patients in 2 hospitals, respectively, during 1995 to 1996. M11 was isolated from 13 patients in 4 hospitals during 1996. A total of 23 of 28 hospitals had evidence of clonal dissemination of some isolates. Plasmid content and hybridization analysis done on 103 isolates from 1 hospital and 2 affiliated extended-care facilities indicated that the strains contained from one to eight plasmids.

Mating experiments indicated transfer of vancomycin resistance from 94 of these isolates into plasmidfree $E$ faecium GE-1 at transfer frequencies of $<10^{-9}$ to $10^{-4}$. Gentam- icin resistance and erythromycin resistance were cotransferred at various frequencies. A probe for the $\operatorname{van} \mathrm{A}$ gene hybridized to the plasmids of 23 isolates and to the chromosomes of 72 isolates. A probe for the $\operatorname{van} \mathrm{B}$ gene hybridized to the chromosomes of 8 isolates.

The results of this study suggest interhospital and intrahospital dissemination of vancomycin-resistant $E$ faecium strains over a 6 -year period in southeastern Michigan. The majority of isolates studied belonged to the same few PFGE strains, indicating that clonal dissemination was responsible for most of the spread of resistance that occurred.

From: Thal L, Donabedian S, Robinson-Dunn B, Chow JW, Dembry L, Clewell DB, et al. Molecular analysis of glycopeptide-resistant Enterococcus faecium isolates collected from Michigan hospitals over a 6-year period. J Clin Microbiol 1998;36:3303-3308. 